\title{
Implementasi Kebijakan Ruang Terbuka Hijau di Kawasan Perkotaan (Studi Pengembangan di Kota Administrasi Jakarta Utara)
}

\section{The Implementation of Green Open Space Policy in Urban Areas (A Development Study in North Jakarta Administrative City)}

\author{
Hendra Wijayanto, Ratih Kurnia Hidayati \\ Universitas 17 Agustus 1945 Jakarta \\ hendra.pelajar@gmail.com, ratihkurnia20@gmail.com
}

\begin{abstract}
Abstrak
Undang-Undang Nomor 26 Tahun 2007 mengamanatkan bahwa di setiap kota harus memiliki Ruang Terbuka Hijau (RTH) minimal sebesar 30\%, dimana sebesar $20 \%$ RTH publik dan $10 \%$ RTH privat. Persentase luas RTH Jakarta Utara yang dimiliki saat ini baru sebesar 5\% dari luasan wilayahnya. Penelitian ini membahas mengenai "Implementasi Kebijakan Rencana Tata Ruang Wilayah dalam Penyediaan Ruang Terbuka Hijau di Kota Administrasi Jakarta Utara. Penelitian ini bertujuan menganalisis implementasi kebijakan RTRW dalam penyediaanruang terbuka hijau di Jakarta Utara dan upaya-upaya yang dilakukan dalam penyediaan ruang terbuka hijau di Kota Administrasi Jakarta Utara. Metode yang digunakan dalam penelitian ini adalah deskriptif dengan pendekatan kualitatif. Teknik pengumpulan data yang digunakan yaitu wawancara, dokumentasi, dan observasi.Teknik analisa data interaktif yang meliputi reduksi data, penyajian data, dan penarikan kesimpulan/verifikasi. Uji validitas data dilakukan dengan menggunakan triangulasi sumber.Hasil penelitian menunjukkan bahwa implementasi kebijakan RTRW dalam penyediaan ruang terbuka hijau di Kota Administrasi Jakarta Utara masih belum optimal dan baru terealisasi sebesar 10\%, dikarenakan penggunaan lahan yang tersedia untuk RTH tidak difungsikan sebagaimana peruntukannya dan adanya beberapa kendala yang dihadapi seperti lemahnya pengawasan, harga tanah yang mahal, peningkatan lahan terbangun dan kurangnya sosialisasi kepada masyarakat.
\end{abstract}

Kata kunci: Implementasi, Kebijakan, Rencana Tata Ruang Wilayah, Ruang Terbuka Hijau

\begin{abstract}
Law Number 26 of 2007 mandates that every city should have Green Open Space (RTH) at least 30\% consisting of 20\% Public Open Space (RTH Publik) and 10\% Private Open Space (RTH Private). This research discussed "The implementation of
\end{abstract}


Area Spatial Layout Plan (thereafter called RTRW) Policy in Providing Green Open Space in North Jakarta Administrative City. This research aimed to analyze the implementation of RTRW policy in providing green open space in North Jakarta and the attempts taken in providing green open space in North Jakarta Administrative City. The method employed in this research was descriptive one with qualitative approach. Techniques of collecting data used were interview, documentation, and observation. Technique of analyzing data used was an interactive one encompassing data reduction, data display, and conclusion drawing/verification. Data validation was carried out using source triangulation. The result of research showed that the implementation of RTRW policy in providing green open space in North Jakarta Administrative City had not been optimal and had just been realized of $10 \%$, due to the land available for RTH not functioned as its allocation and some constraints encountered such as poor supervision, expensive land price, increased number of constructed land, and inadequate socialization to society.

\section{Keywords: Implementation, Policy, Area Spatial Layout Plan, Green Open Space}

\section{A. Pendahuluan}

Undang-Undang Nomor 26 Tahun 2007 tentang Penataan Ruang telah mengamanatkan bahwa setiap kota dalam rencana tata ruang wilayahnya diwajibkan untuk mengalokasikan sedikitnya $30 \%$ dari ruang atau wilayahnya untuk RTH, dimana $20 \%$ diperuntukkan bagi RTH publik dan $10 \%$ diperuntukkan bagi RTH privat pada lahan-lahan yang dimiliki oleh swasta atau masyarakat. Pengembangan, penataan, dan pemenuhan ruang terbuka hijau bagi seluruh komponen lingkungan hidup perkotaan menjadi tanggung jawab seluruh pemangku kepentingan baik pemerintah pusat, provinsi, atau daerah, swasta, dan masyarakat.

Untuk menciptakan pembangunan yang berwawasan lingkungan yang dalam hal ini terkait dengan ketersediaan

RTH tidak hanya memerlukan perencanaan yang baik tetapi juga memerlukan pengawasan dalam implementasi atau pelaksanaan dari perencanaan tersebut.Pengawasan berorientasi pada tujuan organisasi, perencanaan dan pelaksanaannya. Pengawasan dalam penyediaan RTH menjadi sangat penting seiring dengan pesatnya kemajuan dan perkembangan teknologi serta pembangunanpembangunan di kota-kota besar yang ada di Indonesia saat ini.

Jakarta Utara merupakan bagian dari provinsi DKI Jakarta yang tidak luput dari pembangunan dan pengembangan wilayah. Meningkatnya aktivitas pembangunan serta perkembangan wilayah di Jakarta Utara berdampak pada meningkatnya dinamika 
penggunaan lahan. Luasan lahan yang relatif tetap tetapi permintaan lahan yang terus meningkat menyebabkan proses alih fungsi lahan terutama Ruang Terbuka Hijau di Kota Jakarta Utara tidak terelakkan lagi. Berdasarkan data dari Suku Dinas Pertamanan dan Pemakaman Jakarta Utara, pada tahun 2014 Jakarta Utara hanya memiliki lahan RTH sebesar 5\% dari luasan wilayahnya. Persentase luas RTH tersebut tentu masih jauh dari apa yang diamanatkan dalam undangundang yang mengamanatkan proporsi RTH pada wilayah kota paling sedikit $30 \%$ dari luas wilayah kota (Pasal 29 Ayat 2 Undang-Undang Nomor 26 Tahun 2007 tentang PenataanRuang).

Tujuan dari penelitian ini adalah untuk menganalisis senajuh mana implementasi kebijakan RTRW dalam penyediaan ruang terbuka hijau di Kota Administrasi Jakarta Utara, kendalakendala yang dihadapi, dan upayaupaya yang dilakukan untuk meningkatkan implementasi kebijakan RTRW dalam penyediaan ruang terbuka hijau di Kota Administrasi JakartaUtara. Untuk menganalisis dan menjawab permasalahan dalam penelitian ini digunakan beberapa teori yang relevan. Terkait dengan implementasi kebijakan, Grindle (dalam Subarsono, 2005:89) menjelaskan bahwa ada beberapa factor yang mempengaruhi implementasi kebijakan (dalam hal ini adalah implementasi kebijakan terkait penyediaan ruang terbuka hijau di Kota Administrasi Jakarta Utara), yang meliputi:

a. Isi kebijakan (content of policy)mencakup:

1. Interest

Affected/Kepentingan yang Mempengaruhi;Dalam hal ini akan dilihat sejauh mana kepentingan kelompok sasaran yaitu masyarakat Kota Administrasi Jakarta Utara termuat dalam isi kebijakan penyediaan ruang terbuka hijau.

2. Type of Benefits/ TipeManfaat;Bagian ini lebih menekankan pada jenis manfaat yang diterima oleh kelompok sasaran baik pemerintah daerah maupun masyarakat Kota Administrasi Jakarta Utara terkait implementasi kebijakan RTRW dalam penyediaan ruang terbuka hijau di KotaAdministrasi Jakarta Utara.

3. Extent of Change Envision/ Derajat Perubahan yang InginDicapai;Dalam hal ini akan dilihat sejauh mana perubahan yang diinginkan dari kebijakan RTRW dalam penyediaan ruang terbuka hijaudiKota AdministrasiJakarta Utara. 
4. Site of Decision

Making/Letak Pengambilan

Keputusan (Apakah letak sebuah program untuk mendukung kebijakan RTRW

dalam penyediaan ruang terbuka

hijaudiKotaAdministrasiJakar ta Utara sudahtepat);

5. Program Implementors/ Pelaksana Program (Apakah sebuah program telah menyebutkan implementornya dengan rinci);

\section{Resources}

Committed/Sumber-sumber

Daya yang Digunakan, dalam hal ini adalah sumber-sumber daya yang dibutuhkan untuk mendukung kebijakan RTRW dalam penyediaan ruangterbukahijaudi Kota Administrasi Jakarta Utara.

b. Lingkungan implementasi (context of implementation) mencakup:

1. Power, Interest, and Strategy of Actor Involved/Kekuasaan, Kepentingan- kepentingan, dan Strategi dari Aktor yang Terlibat (Seberapa besar kekuasaan, kepentingan, dan strategi yang dimiliki oleh para stakeholders yang terlibat dalam implementasi kebijakan RTRW dalam penyediaan ruang terbuka hijau di Kota Administrasi Jakarta Utara);

2. Institution and Regime Characteristic/ Karakteristik Lembaga dan Rezim yang sedangBerkuasa;

3. Compliance and Responsiveness/ Tingkat Kepatuhan dan Adanya Respon dariPelaksana.

Terkait tata ruang kota, Mirsa (2011:15) mengatakan bahwa: "dalam perencanaan, perancangan dan pemrograman prasarana kota, hal utama yang perlu diperhatikan terhadap elemen tata ruang kota itu sendiri adalah penyusunan perencanaan, pemanfaatan dan pengendalian". Dengan memperhatikan hal tersebut, pemanfaatan dari unsur-unsur atau elemen-elemen dari tata ruang kota yang dalam hal ini adalah Kota Administrasi Jakarta Utara akan lebih terarah terutama dalam mewujudkan pembangunan kota yang berwawasan lingkungan. Dalam perencanaan kotaitu sendiri dikenal istilah ruang terbuka (open space) yaitu tempat terbuka di lingkungan perkotaan, ruang terbuka itu terdiri atas ruang terbuka hijau dan ruang terbuka non hijau (Pancawati, 2010:6).

Ruang terbuka hijau di wilayah perkotaan merupakan bagian dari penataan ruang kota yang berfungsi sebagai kawasan hijau pertamanan kota, 
kawasan hijau hutan kota, kawasan hijau rekreasi kota, kawasan hijau kegiatan olahraga kota, kawasan hijau pemakaman, kawasan hijau pertanian, kawasan jalur hijau, dan kawasan hijau pekarangan (Fattah,2001:11). Masalah penelitian dapat diidentifikasikan sebagai berikut:

1. Persentase luas ruang terbuka hijau di Jakarta Utara belum memenuhi standar yang telah ditetapkan dalam undang-undang maupun peraturan daerah yang ada;

2. Adanya peningkatan alih fungsi lahan terbukahijau untuk pembangunan fisik;

3. Kurangnya pengelolaan terhadap ruang terbuka hijau yang sudah ada;

4. Adanya peningkatan jumlah penduduk di Jakarta Utara tiap tahunnya namun tidak diiringi dengan pertambahan lahan;

5. Masih kurangnya pengawasan terhadap pengelolaan dan penyediaan ruang terbuka hijau;

6. Tidak seimbangnya pertumbuhan pembangunan fisik dengan ketersediaan lahan terbuka hijau di Jakarta Utara.

Dari permasalahan yang diuraikan di atas, maka penulis membatasi masalah pada implementasi kebijakan RTRW dalam penyediaanruangterbuka hijaudi Kota Administrasi Jakarta Utara terkait dengan persentase luasan yang belum memenuhi standar. Adapun rumusan masalah sebagai berikut:
1. Bagaimana implementasi kebijakan Rencana Tata Ruang Wilayah dalam penyediaan ruang terbuka hijau di KotaAdministrasi Jakarta Utara?

2. Apa saja kendala yang dihadapi dalam implementasi kebijakan Rencana Tata Ruang Wilayah dalam penyediaan ruang terbuka hijau di KotaAdministrasi Jakarta Utara?

3. Upaya apa saja yang dilakukan untuk meningkatkan implementasi kebijakan Rencana Tata Ruang Wilayah dalam penyediaan ruang terbuka hijau di KotaAdministrasi Jakarta Utara?

\section{B. Metode}

Dalam penelitian ini penulis menggunakan metode deskriptif dimana penulis akan menggambarkan atau mendeskripsikan secara sistematis dan aktual mengenai fakta-fakta maupun fenomena-fenomena yang dijumpai di lapangan pada saat penelitian terkait dengan implementasi kebijakan RTRW dalam penyediaan ruang terbuka hijau di Kota Administrasi Jakarta Utara. Adapun pendekatan penelitian yang digunakan penulis adalah pendekatan induktif dimana kasus-kasus atau fenomenafenomena khusus yang dijumpai penulis di lapangan nantinya akan menjadi bahan untuk diperolehnya suatu kesimpulan. 
Adapun kebijakan yang telah dikeluarkan oleh Pemerintah DKI Jakarta terkait penyediaan RTH adalah berupa Peraturan Daerah Nomor 1 Tahun 2012 tentang Rencana Tata Ruang Wilayah 2030 DKI Jakartayang terdiri dari rencana tata ruang provinsi, rencana tata ruang kota administrasi yang di dalamnya termasuk Kota Administrasi JakartaUtara, dan rencana tata ruang kabupaten administrasi. Dalam peraturan ini ditegaskan kembali bahwa keberadaan RTH memegang peranan yang sangat penting dalam kelangsungan hidup manusia. Untuk wilayah Jakarta Utara sendiri, keberadaan RTH diarahkan untuk fungsi dan manfaat sebagai berikut:

a. Sebagai fasilitas pelayanan umum untukmasyarakatsepertiuntukmelaku kankegiatan aktif dan pasif, antaralain:rekreasi,olahraga, wisata hutan, danlain-lain.

b. Sebagai pengaman yang sangat penting dalam upaya meningkatkan daya resap tanah terhadap air hujan ke dalamtanah;

c. Sebagai penyeimbang iklim mikro yang muncul akibat kemajuanteknologi;

d. Sebagai pengendali bahan-bahan polutan sehingga pencemaran dapat ditekan seminimal mungkin;dan

e. Sebagai habitat satwa liar dan tempat konservasi plasma nutfah serta tempat keanekaragaman hayati.

\section{Implementasi \\ Kebijakan \\ RuangTerbuka Hijau di Kota \\ Administrasi Jakarta Utara}

Dalam menganalisis permasalahan terkait dengan implementasi kebijakan ruang terbuka hijau di Kota Administrasi Jakarta Utara dapat dilihat dari aspek isi kebijakan dan lingkungan implementasi..

1.Isi Kebijakan, meliputi:

a. Kepentingan yang mempengaruhi kebijakan RTRW dalam Penyediaan Ruang TerbukaHijau

Dalam hal penyediaan ruang terbuka hijau Jakarta Utara,pemerintah mengacu pada beberapa kebijakan yang terkait.Kebijakan ini adalah kebijakan yang diterapkan pada tingkat nasional dan tingkat lokal itu sendiri. Kebijakan ini dianggap memiliki efek pada bagaimana cara pemerintah mengatur dan mengelola RTH perkotaantanpa ada kepentingan-kepentingan lain yang mempengaruhi di dalamnya. Pelaksanaan kebijakan Rencana Tata Ruang Wilayah dalam Penyediaan Ruang Terbuka Hijau di Jakarta Utara telah dijalankan berdasarkan arahan yang ada tanpa pengaruh dari kepentingan - kepentingan dalam bentuk apapun yang dapat menghambat terwujudnya 
implementasi kebijakantersebut.

b. Jenis manfaat yang dihasilkan dari kebijakan RTRW dalam penyediaan ruang terbuka hijaudi Jakarta Utara tahun 2030 dimaksudkan untuk menjamin tersedianya ruang yang cukupbagi:

1. Kawasan konservasi untuk kelestarian hidrologis;

2. Area pengembangan keanekaragaman hayati;

3. Area penciptaan

4. Tempat rekreasi dan olahraga masyarakat;

5. Tempat pemakamanumum;

6. Pembatas perkembangan kota ke arah yang tidak diharapkan;

7. Pengamanan sumber daya alam, buatan maupun historis.

c. Derajat Perubahan yang Ingin Dicapai dari Kebijakan Penyediaan Ruang Terbuka Hijau.

Kondisi saat ini menunjukkan bahwa Jakarta Utara kurang memiliki RTH. Dalam Rencana Tata Ruang Wilayah (RTRW) Jakarta 2011-2030, pemerintah telah menyiapkan target ruang terbuka hijau sebesar 13,94\% dari luas wilayahnya. Ini berarti bahwa pemerintah perlu memberikan tambahan 8,94\% RTH dari RTH eksisting saat ini. Dengan peningkatan luasan
RTH yang kurang dari $1 \%$ dalam kurun waktu 10 tahun terakhir, maka akan memakan waktu yang lamauntuk wilayah Jakarta Utara dalam mewujudkan target RTH yang ingin dicapai, apalagi untuk memiliki jumlah ideal RTH sesuai kebutuhan.

d. Kedudukan Implementor Kebijakan Rencana Tata Ruang Wilayah dalam Penyediaan

iklim rRikang därlpekredthljaipolutan; Implementor kebijakan tentunya mempunyai peran penting dalam melaksanakan kebijakan yang telah ditetapkan yang dalam hal ini adalah kebijakan Rencana Tata Ruang Wilayah dalam Penyediaan Ruang Terbuka Hijau di Jakarta Utara.Peran implementor kebijakan tentunya dapat menjadi tolak ukur keberhasilan implementasi kebijakan dalam penyediaan RTH di Jakarta Utara. Artinya, apabila implementasi kebijakan RTH belum secara optimal direalisasikan maka peran implementor kebijakan dipertanyakan.

e. Pelaksana Program Rencana Tata Ruang Wilayah dalam Penyediaan Ruang Terbuka Hijau

Dalam hal penyediaan, pemeliharaan dan pengendalian 
ruang terbuka hijau Jakarta Utara dilakukan oleh dinasdinas maupun suku dinas yang sesuai dengan lokasi ruang terbuka hijau yang akan disediakan maupun yang sudah tersedia, diantaranya adalah Suku Dinas Pertamanan dan Pemakaman Jakarta Utara di bawah koordinasi Dinas Pertamanan dan Pemakaman Provinsi DKI Jakarta dan Suku Dinas Tata Ruang Jakarta Utara di bawah koordinasi Dinas Tata Ruang Provinsi DKI Jakarta. Adapun dalam hal perencanaan, pelaksanaan dan hasil evaluasi penyediaan, pemanfaatan dan pengendaliannya

dikoordinasikan terlebih dahulu dengan Badan Perencanaan Pembangunan Daerah Provinsi DKI Jakarta.

f. Sumber Daya yang Digunakan dalam Penyediaan Ruang TerbukaHijau

Dalam pelaksanaan suatu kegiatan tentunya akan membutuhkan sumber daya yang potensial untuk mendukung keberhasilan terlaksananya kegiatan tersebut. Begitu juga halnya dengan penyediaan ruang terbuka hijau. Untuk wilayah Jakarta Utara sendiri, sumber daya yang digunakan dalam penyediaan ruang terbuka hijau masih

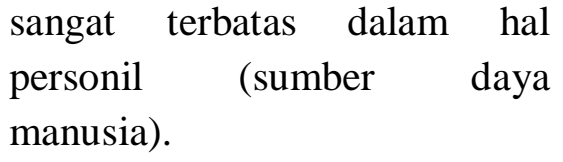

\section{Lingkungan Implementasi,} meliputi:

a. Kekuasaan, kepentingan dan strategi dari actor yang terlibat dalam penyediaan ruang terbuka hijau di Kota Administrasi Jakarta Utara.

Terkait dengan penyediaan ruang terbuka hijau di Jakarta Utara, kekuasaan dan kepentingan dari aktor yang terlibat di dalamnya tidak dominan berpengaruh terhadap kebijakan tersebut. Dalam hal ini suku dinas-suku dinas terkait seperti Suku Dinas Pertamanan dan Pemakaman Jakarta Utara dan Suku Dinas Tata Ruang Jakarta Utara sebagai stakeholders langsung di lapangan memegang peranan penting dalam hal penyediaan RTH sesuai dengan rencana tata ruang dan wilayahyang ada. Dalam pelaksanaannya, suku dinas-suku dinas tersebut selalu berkoordinasi dengan dinasdinas yang terkait langsung, yang dalam hal ini adalah Dinas Pertamanan dan Pemakaman Provinsi DKI Jakarta dan Dinas Tata Ruang Provinsi DKI Jakarta. Adanya koordinasi tersebut dilakukan adalah untuk menghindari munculnya 
kepentingan- kepentingan lain yang dapat menghambat pelaksanaan dari penyediaan RTH tersebut.

b. Karakteristik lembaga atau institusi yang akan turut mempengaruhi penyediaan ruang terbuka hijau di Kota Administrasi Jakarta Utara

Penyediaan RTH di Jakarta Utara melibatkan institusi yang berbeda dalam struktur organisasi pemerintahannya. Instansi teknis yang memiliki tanggung jawab dalam penyediaan RTH di Jakarta Utara adalah Suku Dinas Pertamanan dan Pemakaman Jakarta Utara yang berkoordinasi dengan Dinas Pertamanan dan Pemakaman Provinsi DKI Jakarta dan Suku Dinas Tata Ruang Jakarta Utara yang berkoordinasi dengan Dinas Tata Ruang Provinsi DKI Jakarta. Suku dinas-suku dinas ini bekerja sama dengan institusi lain dalam melaksanakan tugas dan fungsinya dalam penyediaan RTH.

\section{Kendala}

1. Lemahnya Pengawasan TerhadapPenggunaan Lahan danBangunan

Masih adanya intervensi berbagai pihak mengakibatkan pengawasan terhadap pelanggaran $\begin{array}{r}\text { ketentuan } \\ \text { penggunaan lahan dan }\end{array}$ bangunan menjadi lemah. Selain itu, pengawasan yang dilakukan Pemerintah Jakarta Utara dalam hal ini instansi terkait yang mengeluarkan perizinan hanya dapat dilakukan saat masyarakat mengajukan permohonan perizinan. Lemahnya pengawasan pada dasarnya dikarenakan tidak adanya ketentuan hukum yang menegaskan pembolehan penertiban terhadap bangunan yang menggunakan lahan RTH.

2. Harga Tanah yangMahal Penyediaan RTH di perkotaan dihadapkan pada terbatasnya tanah yang dikuasai pemerintah sedangkan tanah yang tidak terbangun harus dibeli pemerintah dengan mahal secara bertahap karena anggaran pemerintah yang tidak mencukupi dan adanya sektorsektor yang juga memerlukan pembiayaan. Penahapanpenahapan dalam pembelian tanah juga menghadapi tingginya tingkat pembangunan fisik oleh masyarakat sehingga harus diperhitungkan kemungkinan tidak tersedianya tanah yang tidak terbangun di masa yang akan datang.

3. Peningkatan LahanTerbangun Peningkatan lahan terbangun di 
Jakarta Utara telah terjadi di beberapa kecamatan. Lahanlahan yang semestinya dapat dimanfaatkan sebagai RTH justru berubah menjadi bangunan - bangunan pertokoan, gedung perkantoran, perumahan dan sebagainya. Diantaranya Pantai Indah Kapuk (PIK). Dulunya, kawasan itu ditetapkan sebagai zona hutan lindung bakau, hutan wisata, dan pengamanan banjir Cengkareng. Namun, kini kawasan tersebut sudah berubah menjadi perumahan dan area komersial, walaupun masih ada sebagian kecil yang diperuntukan untuk hutan bakau. Demikian pula dengan Kelapa Gading. Kini kawasan tersebut sudah berubah menjadi permukiman dan area komersial. Padahal, dulunya ditetapkan sebagai kawasan yang berfungsi sebagai rawa, sawah, dan daerah resapan air.Berdasarkan datayang diperolehdariSukuDinasTataRu angJakarta Utara bahwa luas kawasan terbangun di Jakarta Utara tahun 2015 adalah 7.836,50 Ha sehingga luas lahan Jakarta Utara yang dapat dimanfaatkan untuk RTH adalah 6.736,50 Ha dan sudah termasuk luas RTH saat ini serta lahan terbuka yang belum dimanfaatkan baik milik pemerintah maupun masyarakat.

4. Kurangnya sosialisasi kepada masyarakat Pasal 2 (dua) poin c Permenpu Nomor 5 Tahun 2008 menyatakan bahwa maksud dari Pedoman Penyediaan dan Pemanfaatan Ruang Terbuka Hijau di Kawasan Perkotaan adalah memberikan bahan sosialisasi publik mengenai arti pentingnya ruang terbukahijau bagi kehidupan masyarakat perkotaan dan pada poin $d$ untuk memberikan informasi yang seluas-luasnya kepada masyarakat dan pihak-pihak terkait tentang perlunya ruang terbuka hijau sebagai pembentuk ruang yang nyaman untuk beraktivitas dan bertempat tinggal. Namun, sosialisasi yang dilakukan mengenai ruang terbuka hijau di Jakarta Utara belum maksimal padahal pelibatan masyarakat dalam penyediaan ruang terbuka hijau sangat diperlukan. Sektor pendidikan formal di Jakarta Utara juga tidak memberikan pendidikan tentang pentingnya ruang terbuka hijau sehingga kesadaran terhadap RTH sejak anak-anak hingga dewasa tidak terbentuk. 
D. Upaya-Upaya yang Dilakukan untuk Meningkatkan Penyediaan Ruang Terbuka Hijau Di Kota Administrasi Jakarta Utara

1. Persyaratan Penyediaan RTH pada Penerbitan Izin Mendirikan Bangunan (IMB). Peningkatan lahan terbangun di Jakarta Utara dan terbatasnya tanah pemerintah serta dana untuk membeli lahan masyarakat mengakibatkan penyediaan RTH menjadi sulit. Pemerintah Jakarta Utara memerlukan inovasi kebijakan agar antara kebutuhan pembangunan fisik dan RTH dapat bersesuaian. Oleh karena iturencana penyediaan RTH privat melalui penerbitan Izin Mendirikan Bangunan (IMB) sebagai upaya untuk mengatasi permasalahan tersebut. Hal ini merupakan inovasi dari kebijakan sebelumnya yang hanya memberikan plot pada prosesperizinan.

2. Pembelian tanah

Tanah merupakan aset yang berhargasecara ekonomi maupun sosial bagi masyarakat baik di perkotaan maupun pedesaan. Tanah yang berada di perkotaan penggunaannya selalu dilakukaan secara maksimal maka harga tanah di perkotaan lebih mahal dibandingkan di pedesaan.
Namun, tanah di perkotaan sebagian besar sudah dikuasai masyarakat sehingga pemerintah kesulitan dalam memberikan pengaruh terhadap tata ruang kota termasuk ruang terbuka hijau. Pembebasan tanah dengan cara membeli tanah masyarakat merupakan salah satu upaya yang ditempuh pemerintah Kota Administrasi Jakarta Utara dalam menyediakan ruang terbuka hijau. Berdasarkan data materi teknis RTRW Jakarta Utara, Pengadaan Tanah untuk Taman \& TPU akan dilakukan dari awal hingga akhir periode RTRW Jakarta Utara.

3. Pemanfaatan lahanpublik Jakarta Utara mempunyai median jalan yang lebar, seperti Jalan Boulevard Bar.Raya memiliki lebar median jalan \pm 3-4 meter dan belum termasuk sempadan jalan yang pada umumnya lebih lebar dibandingkan median jalannya. Pemanfaatan areal-areal tersebut sebagai RTH tentunya akan sangat menguntungkan bagi penambahan ketersediaan RTH Jakarta Utara. Oleh karena itu, pemanfaatan areal atau lahan publik tersebut selain memberikan nilai estetika, namun juga menyeimbangkan lingkungan dengan fungsinya sebagai ruang terbuka hijau di Jakarta Utara.

4. Penyediaan RTH Melalui Taman Atap (Roof Garden) 
Taman atap (roof garden) merupakan salah satu sarana untuk menyediakan RTH di perkotaan. Pengelola RTH di Jakarta Utara merencanakan untuk mengajukanpembuatan kebijakan mengenai taman atap kepada Pemerintah Provinsi DKI Jakarta sebagai upaya untuk menyediakan kekurangan luas RTH. Permenpu Nomor 5 Tahun 2008 tentang Pedoman Penyediaan dan Pemanfaatan Ruang Terbuka Hijau di Kawasan Perkotaan menyatakan bahwa taman atap dapat dilakukan pada kondisi luas lahan terbuka terbatas atau lahan dengan Koefisien Dasar Bangunan (KDB) di atas 90\%, seperti pada kawasan pertokoan di pusat kota, atau pada kawasan-kawasan dengan kepadatan tinggi. Oleh karena itu, rencana taman atap (roof garden) ini akan diterapkan pada kawasan- kawasan yang padat dengan bangunanbangunan beratap semen.

\section{E. Kesimpulan}

Berdasarkan hasil penelitian dan pembahasan yang telah diuraikan, maka kesimpulan yang diperoleh antara lain:

1. Implementasi kebijakan Rencana TataRuang Wilayah dalam Penyediaan Ruang Terbuka Hijau di Kota Administrasi Jakarta
Utara masih belum optimal dan baru terealisasi sebesar 5\%. Hal ini dikarenakan penggunaan lahan yang tersedia untuk RTH tidak difungsikan sebagaimana peruntukannya. Sementara itu, proses kebijakan penyediaan RTH itu masih berada pada tataranformulatif yaitu dengan dirumuskannya Peraturan Daerah Nomor 1 Tahun 2012 tentang Rencana Tata Ruang Wilayah 2030 tetapi secara implementatif sebagaimana Perda itu dijalankan oleh Suku Dinas Pertamanan dan Pemakaman sebagai leading sector dalam upaya penyediaan RTH masih banyak menemui kendala.

2 Kendala-kendala yang dihadapi dalam mewujudkan implementasi kebijakan Rencana Tata Ruang Wilayah dalam Penyediaan Ruang Terbuka Hijau di Kota Administrasi Jakarta Utara antara lain: (a) lemahnya pengawasan terhadap penggunaan lahan dan bangunan; (b) harga tanah yang mahal; (c) peningkatan lahan terbangun;dan(d) kurangnya sosialisasi kepada masyarakat mengenai arti pentingnya ruang terbukahijau bagi kehidupan masyarakat perkotaan.

Upaya-upaya yang dilakukan dalam mewujudkan implementasi kebijakan Rencana Tata Ruang Wilayah dalam Penyediaan Ruang 
Terbuka Hijau di Kota Administrasi Jakarta Utara antara lain: (a)persyaratan penyediaan RTH pada penerbitan Izin Mendirikan Bangunan (IMB); (b) pembelian tanah masyarakat oleh pemerintah; (c) pemanfaatan lahan publik sebagai ruang terbuka hijau; dan (d) penyediaan RTH melalui taman atap (roof garden) pada kawasan-kawasan yang padat dengan bangunanbangunan beratap semen.

Adapun saran-saran pada penelitian ini adalah sebagai berikut:

1. Perlunya sebuah political will dari pemerintah untuk mewujudkan ketersediaan ruang terbuka hijau sesuai dengan amanat dari undang-undang yakni minimal sebesar $30 \%$, mengingat bahwa RTH kota tidaklah hanya sekedar pelengkap suatu Rencana Umum Tata Ruang Kota tetapi lebih dariitu keberadaan RTH kota adalah sebagai "alat kendali" kerusakan (fisik) lingkungan lebih lanjut.

2. Perlu adanya suatu kajian oleh pemerintah untuk menjadikan Jakarta hanya sebagai pusat pemerintahan saja, mengingat bahwa selama ini peran Jakarta sebagai pusat ekonomi, bisnis, pariwisata dan juga pemerintahan membuat padatnya penduduk sehingga berdampak pada tidak terkendalinya pemanfaatan ruangruang kota khususnya ruang terbukahijau.

3. Pemerintah perlu melakukan pengawasan yang lebih ketat terhadap penyediaan ruang terbuka hijau serta adanya pemberlakuan sanksi yang tegas kepada siapapun yang melanggar aturan terkait penyediaan ruang terbukahijau.

\section{Daftar Pustaka}

Bambang. 1994. Hukum dan Kebijaksanaan Publik. Jakarta: Sinar Grafika.

Fattah, N. 2001.Perencanaan Kota Komprehensif.Bandung:

Angkasa. Hamdi, M. 1999. Bunga Rampai Pemerintahan. Jakarta: YarsifWatampone.

Jenks, Mike dan Nicola Jones. 2010. Future Form and Design for Sustainable Cities. New York: Overlook Press.

Mirsa, Rinaldi. 2011. Elemen Tata Ruang Kota.Yogyakarta: Graha Ilmu.

Nugroho, Riant. 2012. Public Policy: Teori, Manajemen, Dinamika, Analisis, Konvergensi dan Kimia Kebijakan (Edisi 5). Jakarta: Elex MediaKomputindo.

Pancawati, Tuti. 2010. Tata Ruang Perkotaan. Yogyakarta: Pustaka Pelajar.

Peraturan Menteri Pekerjaan Umum 
Nomor 05/PRT/M/2008

tentang Pedoman Penyediaan

dan Pemanfaatan Ruang

Terbuka Hijau di Kawasan

Perkotaan.

Peraturan Daerah Provinsi DKI Jakarta

Nomor 1 Tahun 2012 tentang

Rencana Tata Ruang Wilayah 2030.

Subarsono, A.G. 2005. Analisis Kebijakan Publik: Konsep, Teori dan Aplikasi.

Yogyakarta: Pustaka Pelajar.

Undang-Undang Nomor 26 Tahun 2007 tentang Penataan Ruang. 
Spirit Publik Volume 12, Nomor 2, Oktober 2017

Halaman 61-74

P-ISSN. 1907-0489 E-ISSN 2580-3875 